\title{
AKTIVITAS ANTIDIABETES EKSTRAK ETANOL DAUN DAN BATANG SIDAGURI (Sida rhombifolia) TERHADAP MODEL HEWAN DIABETES TIPE 2
}

\author{
Aulia Nurfazri Istiqomah ${ }^{1 *}$, Widhya Aligita ${ }^{1}$, Hendra Mahakam Putra ${ }^{1}$, Denny Galang $^{1}$, Hapipah Nurjamilah ${ }^{1}$ \\ ${ }^{1}$ Universitas Bhakti Kencana; Jalan Soekarno Hatta, Bandung, Kode Pos 40614 \\ e-mail: * aulia.nurfazri@bku.ac.id
}

\begin{abstract}
ABSTRAK
Diabetes merupakan penyakit yang ditandai dengan meningkatnya kadar glukosa dalam darah yang terjadi karena kurangnya produksi insulin atau berhentinya produksi insulin dalam tubuh. Herba Sidaguri (Sida rhombifolia) diketahui memiliki aktifitas sebagai antidiabetes. Penelitian ini dilakukan untuk mengevaluasi aktivitas antidiabetes ekstrak etanol daun dan batang sidaguri (Sida rhombifolia) terhadap model hewan diabetes tipe 2 dan mencari bagian mana yang paling efektif sebagai antidiabetes. Metode penelitian ini merupakan penelitian eksperimental secara in vivo. Mencit dibagi menjadi 9 Kelompok yaitu kelompok kontrol negatif, kontrol positif, Glibenklamid 0,65 mg/KgBB, ekstrak daun sidaguri dosis 3,5; 7; dan 14 mg/KgBB, serta ekstrak batang sidaguri dosis 3,5; 7; dan $14 \mathrm{mg} / \mathrm{KgBB}$. Pengujian dilakukan secara kuratif, hewan uji kecuali kontrol negatif, diberikan induksi aloksan monohidrat $80 \mathrm{mg} / \mathrm{KgBB}$ melalui rute intravena, kemudian setelah 3 hari paska induksi, dilakukan pemeriksaan kadar glukosa darah puasa. Perlakuan dilanjutkan dengan pemberian terapi selama 14 hari melalui rute peroral. Parameter uji pada penelitian ini adalah pengukuran kadar glukosa daraah pada hari ke 0,7 , dan 14, serta histopatologi organ pankreas. Dari hasil pengujian diperoleh bahwa ekstrak yang memberikan efek antidiabetes terbaik adalah ekstrak etanol daun sidaguri dosis $14 \mathrm{mg} / \mathrm{KgBB}$ namun belum mampu memperbaiki kondisi sel-sel pankreas sepenuhnya.
\end{abstract}

Kata Kunci: Aloksan. Diabetes, sidaguri, Sida rhombifolia

\section{ABSTRACT}

Diabetes is a disease characterized by increased levels of glucose in the blood that occur due to a lack of insulin production or the cessation of insulin production in the body. Sidaguri herb (Sida Rhombifolia) is known to have antidiabetic activity. This study was conducted to evaluate the antidiabetic activity of the ethanolic extract of the leaves and stems of sidaguri (Sida rhombifolia) in animal of type 2 diabetes model and to find out which part is the most effective as antidiabetic. This research method is an in vivo experimental study. Mice were divided into 9 groups, that is negative control group, positive control group, Glibenclamide $0.65 \mathrm{mg} / \mathrm{KgBW}$, sidaguri leaf extract at a dose of 3.5 ; 7 ; and $14 \mathrm{mg} / \mathrm{KgBW}$, as well as sidaguri stem extract at a dose of $3.5 ; 7$; and $14 \mathrm{mg} / \mathrm{KgBW}$. The test was carried out curatively, the test animals except negative controls were given induction of alloxan monohydrate $80 \mathrm{mg} / \mathrm{KgBW}$ via the intravenous route, then after 3 days post-induction, fasting blood glucose levels were checked. The treatment was continued by giving therapy for 14 days via the oral route. The test parameters in this study were the measurement of blood glucose levels on days 0,7 , and 14 , and pancreatic histopathology was also performed. The test results show that was found that the extract that gave the best antidiabetic effect was the ethanolic extract of sidaguri leaves at a dose of $14 \mathrm{mg} / \mathrm{KgBW}$ but had not been able to fully improve the condition of the pancreatic cells.

\section{PENDAHULUAN}

Diabetes mellitus (DM) merupakan sekelompok gangguan metabolisme yang ditandai oleh hiperglikemia serta kelainan pada metabolisme karbohidrat, lemak, dan protein (DiPiro, 2015). Angka kejadian DM Nasional maupun global dapat dikatakan masih tinggi. Berdasarkan data study global, jumlah penderita DM semakin meningkat dari tahun ke tahun, jika tidak ada tindakan yang dilakukan, jumlah ini diperkirakan akan meningkat pada tahun 2030 (IDF, 2021). Angka kejadian DM menurut data riskesdas 2013 terjadi peningkatan dari 6,9\% pada tahun 2013 dan meningkat menjadi 8,5\% ditahun 2018 dari keseluruhan penduduk sebanyak 250 juta jiwa (Riskesdas, 2013); (Riskesdas, 2018).

Penatalaksanaan DM secara umum bertujuan untuk meningkatkan kualitas hidup penyandang diabetes. Langkah penatalaksanaan DM salah satunya adalah dengan terapi farmakologis. Terapi farmakologis diberikan bersama pengaturan makan dan latihan jasmani (gaya hidup sehat). Terapi farmakologis terdiri dari obat oral dan bentuk suntikan (Perkeni, 2011).

Obat-obat antidiabetes saat ini mayoritas adalah obat-obatan sintetis yang pada umumnya memiliki efek samping utama hipoglikemia serta efek samping lainnya seperti sakit kepala, mual, muntah, pusing, dan gangguan saluran cerna sehingga banyak penderita Diabetes Mellitus yang beralih menggunakan tanaman obat sebagai alternatif untuk mengendalikan kadar glukosa darah (Prameswari, 2014).

Tanaman Sidaguri merupakan tanaman yang tumbuh liar. Sidaguri dapat tumbuh di tepi jalan, halaman berumput, hutan, ataupun ladang. Diketahui sidaguri mengandung senyawa alkaloid, saponin, tanin, fenol, kalium oksalat, flavonoid, dan steroid. Dari beberapa penelitian sidaguri diketahui memiliki aktifitas antihipergilkemia, antihiperurikemia, dan antibakteri (Simarmata, dkk., 2012); (Dhalwal, dkk., 2010); (Assam, dkk., 2010). Penelitian ini bertujuan untuk mengevaluasi aktivitas antidiabetes ekstrak etanol daun dan batang sidaguri (Sida rhombifolia) terhadap model hewan diabetes tipe 2 . 
Jurnal Penelitian Farmasi Indonesia 10(2), Desember 2021 ISSN : 2302-187X e-ISSN 2656-3614

\section{METODE PENELITIAN}

Penelitian ini adalah penelitian eksperimental menggunakan metode in vivo dan dilakukan secara kuratif terhadap 9 kelompok mencit yang diinduksi aloksan monohidrat $80 \mathrm{mg} / \mathrm{KgBB}$ dan selanjutnya diberikan terapi/zat uji selama 14 hari. Parameter yang diukur adalah kadar glukosa darah 7 dan 14 hari pemberian terapi dan histopatologi organ pankreas.

\section{Alat dan Bahan}

Alat yang digunakan adalah glukometer, rotary evaporator, mikroskop, dan alat gelas lainnya.

Bahan yang digunakan dalam penelitian ini antara lain Glibenklamid, Aloksan, Simplisia daun dan batang sidaguri, Na-CMC, $\mathrm{NaCl}$ Fisiologis, Aquadest, Etanol.

\section{Prosedur}

Mencit dibagi menjadi 9 Kelompok yaitu kelompok kontrol negatif (tidak diberikan induksi dan terapi), kontrol positif (diinduksi aloksan monohidrat 80 $\mathrm{mg} / \mathrm{KgBB}$ ), Kontrol Pembanding (Glibenklamid 0,65 $\mathrm{mg} / \mathrm{KgBB}$ ), ekstrak daun sidaguri dosis $3,5 \mathrm{mg} / \mathrm{KgBB}$, $7 \mathrm{mg} / \mathrm{KgBB}$, dan $14 \mathrm{mg} / \mathrm{KgBB}$, serta ekstrak batang sidaguri dosis 3,5 mg/KgBB, $7 \mathrm{mg} / \mathrm{KgBB}$, dan 14 $\mathrm{mg} / \mathrm{KgBB}$.

Dilakukan induksi aloksan monohidrat $80 \mathrm{mg} / \mathrm{KgBB}$ diberikan secara intravena melalui ekor mencit pada semua kelompok kecuali kontrol negatif (-). 3 hari paska induksi, dilakukan pemeriksaan kadar glukosa darah puasa. Hewan uji dinyatakan diabetes jika kadar glukosa darah puasa $\geq 200 \mathrm{mg} / \mathrm{dl}$ (T0). Pemberian terapi diberikan selama 14 hari secara peroral. Pada hari ke 7(H7) dan 14(H14) dilakukan pengukuran kadar glukosa darah puasa serta pada hari ke 14 dilakukan histopatologi organ pankreas.

\section{Analisis Data}

Analisis data menggunakan statistik One Way ANOVA.

\section{HASIL DAN PEMBAHASAN}

Pada penelitian ini hewan uji yang digunakan adalah mencit putih jantan galur Swiss Webster dengan kondisi sehat yang telah berusia $2-3$ bulan dan memiliki bobot antara $20-30$ gram.

Penelitian yang dilakukan merupakan penelitian eksperimental secara in vivo dengan metode kuratif, yakni dengan memberikan hewan dengan induksi senyawa yang digunakan untuk meningkatkan kadar gula darah dan mencapai tahap hewan berada dalam keadaan diabetes. Penelitian dilakukan selama 14 hari untuk melihat dan mengetahui kemampuan dari ekstrak etanol batang dan daun sidaguri yang akan dibandingkan dengan obat uji yang sudah sering digunakan dalam

pengobatan untuk penderita diabetes yakni glibenklamid dengan dosis $0,65 \mathrm{mg} / \mathrm{KgBB}$.

Semua kelompok uji kecuali kelompok kontrol negatif diberikan aloksan dengan dosis $80 \mathrm{mg} / \mathrm{kgBB}$ dengan tujuan untuk membuat keadaan mencit menjadi diabetes. Salah satu cara untuk mengetahui bahwa hewan uji telah memenuhi persyaratan diabetes pada penelitian adalah saat dilakukan pengecekan nilai dari kadar glukosa dalam darah puasanya sebesar > 200 . Setelah itu dilakukan pengujian dengan memberikan zat uji sesuai dengan pengelompokan yakni Glibenklamid $0,65 \mathrm{mg} / \mathrm{KgBB}$, ekstrak daun sidaguri dosis 3,5 $\mathrm{mg} / \mathrm{KgBB}, 7 \mathrm{mg} / \mathrm{KgBB}$, dan $14 \mathrm{mg} / \mathrm{KgBB}$, serta ekstrak batang sidaguri dosis $3,5 \mathrm{mg} / \mathrm{KgBB}, 7 \mathrm{mg} / \mathrm{KgBB}$, dan $14 \mathrm{mg} / \mathrm{KgBB}$. Dari hasil pengujian diperoleh hasil seperti pada tabel 3.1 dan gambar 3.1

\section{Tabel 3.1 Rerata Kadar Glukosa Darah Pra Induksi, Pasca Induksi, dan Pasca Terapi}

\begin{tabular}{|c|l|l|l|l|c|}
\hline \multirow{2}{*}{ No } & \multicolumn{1}{|c|}{ Kelompok } & \multicolumn{4}{|c|}{ Rerata \pm SD (mg/DL) } \\
\cline { 2 - 6 } & \multicolumn{1}{|c|}{ T0 } & \multicolumn{1}{|c|}{ H0 } & \multicolumn{1}{|c|}{ H7 } & H14 \\
\hline 1 & Kontrol Positif & $88,33 \pm 11,15$ & $373,67 \pm 107,10^{\circ}$ & $421,67 \pm 135,67^{\circ *}$ & $449,67 \pm 122,51^{\circ *}$ \\
\hline 2 & Kontrol Negatif & $106,00 \pm 3,60$ & $95,33 \pm 7,37^{*}$ & $101,00 \pm 2,00^{*}$ & $102,33 \pm 3,78^{*}$ \\
\hline 3 & Pembanding & $84,67 \pm 10,11$ & $257,67 \pm 32,13^{\circ}$ & $188,00 \pm 8,54^{*}$ & $148,67 \pm 20,59^{*}$ \\
\hline 4 & EEDS 3.5 mg/KgBB & $75,67 \pm 16,25$ & $352,33 \pm 54,51^{\circ}$ & $450,33 \pm 123,29^{\circ *}$ & $447,00 \pm 122,29^{\circ *}$ \\
\hline 5 & EEDS 7 mg/KgBB & $87,67 \pm 0,57$ & $303,00 \pm 43,09^{\circ}$ & $268,33 \pm 22,50^{* \circ}$ & $229,67 \pm 23,28^{* \circ}$ \\
\hline 6 & EEDS 14 mg/KgBB & $81,00 \pm 9,53$ & $368,33 \pm 198,28^{\circ}$ & $325,33 \pm 32,34^{\circ *}$ & $255,00 \pm 38,433^{* \circ}$ \\
\hline 7 & EEBS 3.5 m/KgBB & $88,00 \pm 12,53$ & $278,33 \pm 72,57^{\circ}$ & $263,00 \pm 90,33^{* \circ}$ & $256,67 \pm 84,67^{* \circ}$ \\
\hline 8 & EEBS 7 mg/KgB & $91,00 \pm 19,46$ & $307,67 \pm 36,91^{\circ}$ & $256,00 \pm 17,43^{* \circ}$ & $248,00 \pm 12,12^{* \circ}$ \\
\hline 9 & EEBS 14 mg/KgBB & $101,67 \pm 5,13$ & $288,33 \pm 64,45^{\circ}$ & $260,00 \pm 62,45^{* \circ}$ & $244,33 \pm 59,36^{* \circ}$ \\
\hline
\end{tabular}

Keterangan :

Pembending = Glibenclamide $0,65 \mathrm{mg} / \mathrm{dL}$ EEDS $=$ Ekstrak Etanol Daun Sidagur

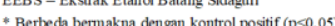

Berbeda bemmakna dengan kontrol positif ( $p<0,05)$

Berbeda bermakna dengan kontrol pembanding $(p<0,05)$

Dari tabel tersebut dapat diketahui bahwa pada pengujian T0 atau sebelum perlakuan, tidak ada perbedaan yang bermakna pada nilai kadar glukosa darah hewan uji di seluruh kelompok uji, hal tersebut menandakan bahwa hewan uji berada dalam kondisi yang relatif sama.

Pada H0 yakni paska pemberian induksi, terlihat bahwa ada perbedaan yang bermakna antara kelompok yang diberikan induksi dibandingkan dengan kontrol negatif. Hal tersebut menandakan bahwa induksi yang diberikan yakni aloksan telah meningkatkan kadar glukosa darah hewan uji. Hewan uji dikatakan mengalami diabetes apabila kadar glukosa darah mencapai lebih dari $200 \mathrm{mg} / \mathrm{dL}$.

Pada pengujian hari ke 7 setelah pemberian terapi terlihat bahawa kelompok ekstrak etanol daun sidaguri dosis $7 \mathrm{mg} / \mathrm{KgBB}$, ekstrak etanol batang sidaguri dosis 3,5; 7; dan $14 \mathrm{mg} / \mathrm{KgBB}$ menunjukkan adanya perbedaan yang bermakna dibandingkan dengan kelompok kontrol positif, hal tersebut menunjukkan bahwa beberapa ekstrak uji telah memberikan efek penurunan kadar glukosa darah pada mencit diabetes.

Pada pengujian hari ke 14 setelah pemberian terapi, terlihat bahwa seluruh kelompok ekstrak uji kecuali ekstrak daun sidaguri dosis 3,5 mg.KgBB 
menunjukkan adanya perbedaan yang bermakna dibandingkan dengan kelompok kontrol positif, hal tersebut menunjukkan bahwa beberapa ekstrak uji telah memberikan efek penurunan kadar glukosa darah.

Untuk melihat dosis mana yang paling efektif dalam menurunkan kadar glukosa darah, dapat dilihat pada gambar 3.1.

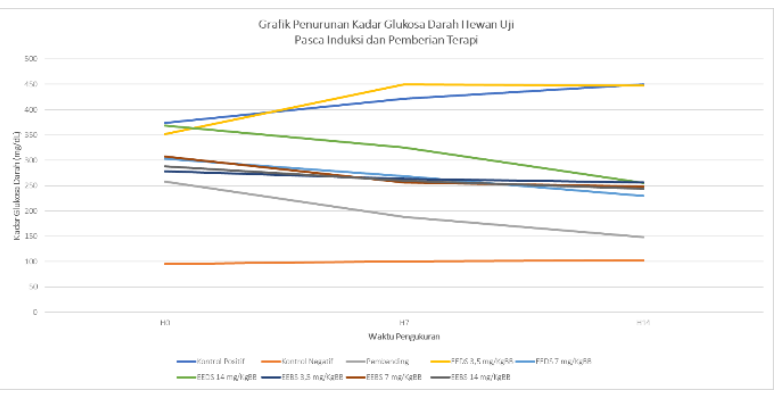

\section{Gambar 3.1 Grafik Penurunan Kadar Glukosa Darah Hewan Uji Pasca Induksi dan Pemberian Terapi}

Dari grafik tersebut dapat dilihat bahwa seluruh kelompok ekstrak uji kecuali ekstrak daun sidaguri dosis 3,5 mg.KgBB dapat memberikan efek penurunan kadar glukosa darah. Kemudian dari grafik tersebut dicari angka kelandaian penurunan kadar glukosa darah. Berdasarkan nilai kelandaian penurunan, diperoleh bahwa ekstrak etanol daun sidaguri dosis $14 \mathrm{mg} . \mathrm{kgBB}$ $(y=-56.667 x+429.56)$ merupakan dosis terbaik dalam penurunan akdar glukosa darah.

Selain dilihat dari angka penurunan kadar glukosa darah, dilakukan juga histopatologi organ pankreas. Diperoleh hasil sebagai berikut :

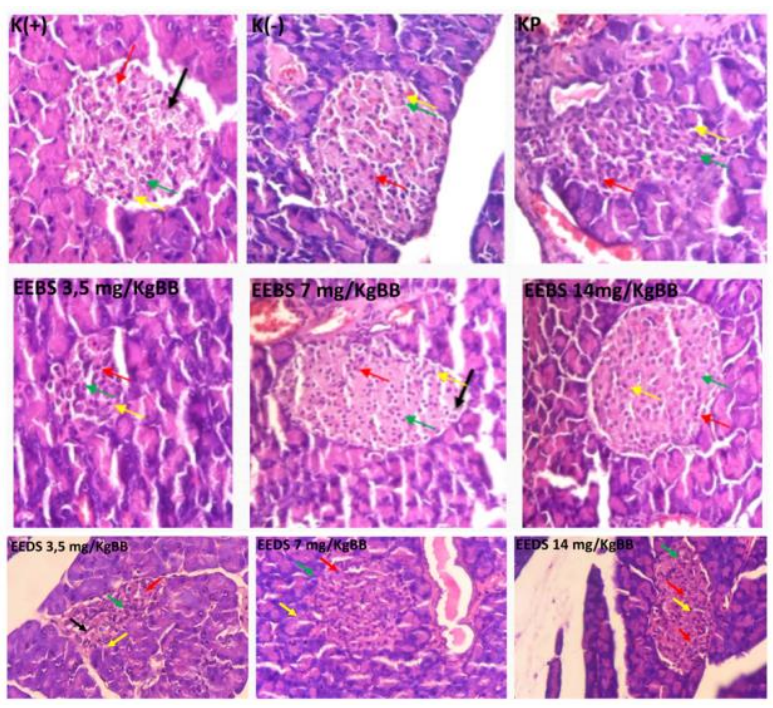

Keterangan : Sel lisis (panah hitam), sel nekrosis (panah merah), sel beta (panah hijau), sel alfa (panah kuning)

Gambar 3.2 Hasil Histopatoogi Organ Pankreas
Pada pengamatan histologi dilakukan untuk mengetahui gambaan dari histologi pulau langerhans pada hewan yang telah diuji. Pada penelitian untuk preparat bahan berupa organ pankreas diberikan pewarnaan hematoksilin eosin (HE). Pewarnaan menggunakan metode tersebut adalah untuk mengetahui gambaran dan memudahkan atau memperjelas pengamatan terhadap komponen sel maupun jaringan dari pulau langerhans yang terlihat pada mikroskop cahaya. Dari gambar tersebut terlihat bahwa masih adanya sel yang mengalami lisis dan neksrosis pada semua zat uji.

Sidaguri diketahui memiliki kandungan flavonoid yang kaya akan antioksidan yang berpotensi sebagai antidiabetes. Dari beberapa penelitian sebelumnya diketahui bahwa ekstrak sidaguri mampu menghambat aktivitas enzim $\alpha$-amilase dan $\alpha$-glukosidase secara in vitro dan in vivo (Bati, dkk., 2018).

\section{KESIMPULAN}

Dari hasil penelitian ini diperoleh bahwa ekstrak etanol daun sidaguri dosis $14 \mathrm{mg} / \mathrm{kgBB}$ menunjukan aktivitas antidiabetes terbaik namun belum mampu memperbaiki kondisi sel-sel pankreas sepenuhnya.

\section{UCAPAN TERIMA KASIH}

Terimaksih kepada Lembaga Penelitian dan Pengabdian Masyarakat serta Fakultas Farmasi Universitas Bhakti kencana yang telah membiayai dan memfasilitasi penelitian ini

\section{DAFTAR PUSTAKA}

DiPiro J.T., Wells B.G., Schwinghammer T.L. and DiPiro C. V., 2015,. Pharmacotherapy Handbook, Ninth Edit., McGraw-Hill Education.

IDF, 2011, 'One Adult In Ten Will Have Diabetes by 2003. (http://www.idf.media-events/press releases/2011/diabetes-atlas8th-edition)

Kementerian Kesehatan RI. 2013. Riset Kesehatan Dasar 2013. Jakarta: Badan Penelitian dan Pengembangan.

Kementerian Kesehatan RI. 2018. Riset Kesehatan Dasar 2018. Jakarta: Badan Penelitian dan Pengembangan.

Perkumpulan Endokrinologi Indonesia (PERKENI) (2011) : Konsensus Pengelolaan dan Pencegahan Diabetes Mellitus Tipe 2 di Indonesia, 4-20.

Prameswari, O.M. dan Widjarnako, S.B. (2014) : Uji Efek Ekstrak Air Daun Pandan Wangi Terhadap Penurunan Kadar Glukosa Darah dan Hispatologi Diabetes Mellitus, Jurnal Pangan dan Agroindustri, 2, 17; 21.

Simarmata, Y. B. C., dkk,, 2012., Efek Hipourikemia Ekstrak Daun Sidaguri (Sida rhombifolia L.) Pada Mencit Jantan., Journal of Pharmaceutics and Pharmacology., Vol.1., Universitas Sumatera Utara., Medan.

Dhalwal, K., Shinde, VM., Singh, B., Mahadik, KR. 2010. Hypoglycemic and hypolipidemic effect of Sida rhombifolia ssp. retusa in diabetic induced animals. International Journal of Phytomedicine. 2 (2).

Assam JPA, Dzoyem J, Pieme C, Penlap V. In vitro antibacterial 
Jurnal Penelitian Farmasi Indonesia 10(2), Desember 2021

ISSN : 2302-187X

e-ISSN 2656-3614

activity and acute toxicity studies of aqueous-methanol extract of Sida rhombifolia Linn. (Malvaceae). BMC Complementary and Alternative Medicine. 2010;10(40): 1-7.
Bati, K., Kwape, T., Chaturvedi, P. 2018. "The Inhibitory Effect of An Ethanol Extract of Sida Rhombifolia Leaves on Key Carbohydrate Hydrolyzing Enzymes." Journal of Complementary Medicine Research 9(2):1 